\title{
Construct Validation of Five Love Languages
}

\author{
Edwin Adrianta Surijah and Yashinta Levy Septiarly \\ Universitas Dhyana Pura
}

\begin{abstract}
Five Love Languages (FLL) is a theory proposed by Chapman (2010) about five ways a person feel most loved. This study was based on a lack of empirical evidence supporting the construct. Therefore, it aimed to validate five love languages and the results of this study were expected to be an empirical evidence to support Chapman's idea. A Likert scale was constructed and tested toward 400 participants (148 males, 252 females; $M_{a g e}=19.85$ years, $S D_{\mathrm{age}}=1.51$ years). The FLL scale showed a promising composite reliability score ( .884$)$ and satisfying item-total correlations (averagely $>.250$ ). Statistical analyses showed that there were 17 valid items in the Five Love Languages Scale. Confirmatory factor analysis supported the five factors in Chapman's initial proposal.
\end{abstract}

Keywords: Five Love Languages, construct validity, factor analysis

Lima bahasa cinta merupakan teori yang pada mulanya digagas oleh Chapman (2010) tentang lima cara individu merasa dicintai. Penelitian ini didasarkan pada sedikitnya temuan bukti empiris yang mendukung teori tersebut. Oleh sebab itu, penelitian ini bertujuan melakukan uji kesahihan teori lima bahasa cinta dan hasil temuan diharapkan dapat memberikan dukungan ilmiah pada konsep Chapman tersebut. Skala Likert disusun dan diujikan pada 400 sampel (148 laki-laki, 252 perempuan; rerata usia $=19.85$ tahun, $S D_{\text {usia }}=1.512$ tahun). Skala FLL menunjukkan reliabilitas komposit yang baik ( .884 ) dan korelasi butir-total yang memuaskan (rata-rata > .250). Hasil analisis statistik menunjukkan adanya 17 butir yang sahih pada skala Five Love Languages. Analisis faktor konfirmatori menegaskan adanya lima komponen faktor penyusun konstruksi skala seperti yang Chapman kemukakan.

Kata kunci: lima bahasa cinta, kesahihan konstruk, analisis faktor

Love, romance, and relationship are popular topics discussed in many different fields. In common population, according to Al-Khalili et al. (2012), "what is love" has been the most searched phrase in the Internet search engines. It shows that people are interested in "love" matter. It also indicates that establishing a sound definition of love is difficult.

The author borrowed an idea from Cookerly (2010), a renown researcher in love subject since 1973. He quoted love as "a powerful, vital, natural process of highly valuing, desiring for, often acting for, and taking pleasure in the well-being of the loved." However, this definition alone would not suffice to cover the complexity of love. As Cookerly has explained, there are different perspectives in understanding love.

Through years particularly in the field of psychology, "love science" has been developed scientifically. Researchers offer a different take on love. For example,

Correspondence concerning this article should be addressed to Edwin Adrianta Surijah,Universitas Dhyana Pura, Jalan Raya Padang Luwih, Bali, 80361. E-mail: edwin@adrianta.com
Fraley and Shaver (2000) explain that the attachment theory is the basis of intimate relationships and adult romantic relationships. Gonzaga, Keltner, Turner, Campos, and Altemus (2006) found a correlation between love and sexual desire. In the same year, Wilkins and Gareis (2006) also investigated the expression of love or declaration of love "I Love You" in a cross-cultural study.

Chapman (2010) in his book "The Five Love Languages: The Secret to Love That Lasts" also offers his view on love. His book has become The New York Times bestseller and sold more than five million copies. It has also been translated into 38 different languages.

Chapman's theory of the five love languages was based on his experiences as a marriage counselor for thirty years. Chapman (2010) concludes that there are five languages of love, five ways men (women) use to speak and understand love or emotions, such as words of affirmation, quality time, receiving gifts, acts of service and physical touch. 
"Words of Affirmation" means people would feel loved when they receive praises or positive feedbacks from their significant others. People in the "Quality Time" category would feel loved when their spouses/ partners give undivided attention toward them. Whereas, the "Receiving Gifts" category befits people who feel loved by getting presents or surprises. "Acts of Service" is the subsequent type where people would feel loved if their spouses or partners help them sincerely. Finally, people feel loved by receiving caressess and skin-to-skin contacts in the "Physical Touch" category.

Although its popularity has been wide-spread across the globe, we have not found a satisfactory scientific evidence other than Chapman's personal defense. Despite that the five love languages has been proposed since 1992, further research and construct validation testing are required to support the theory. A number of studies related to The Five Love Languages have tested the validity of the theory.

Egbert and Polk (2006) tested the validity of Five Love Languages (FLL) to 86 students (and also as couples) at The University of Midwestern. Egbert and Polk developed the FLL scale using of a five forced-choice structure that spatially forces the sample to designate to one of the FLL and 20 items of Likert Scale. The result showed that there were five love languages the same as those expressed by Chapman and this has become the first empirical support for the FLL theory.

In 2013, Polk and Egbert conducted further research on five love languages. This study aimed to test the quality of relationships in terms of the revenue and provision of each love language. Eighty three couples enrolled as students at The University of Midwestern participated in the study. Polk and Egbert added five forced-choice questions despite the original scale of love languages comprising 20 statements of Likert Scale. Polk and Egbert also included the Quality of Relational Inventory Scale. The results showed similarities in the quality of relationships between the pair matched type and mismatched type. They also grouped the couples into 12 combination of pair types based on how the couples felt (passively) loved and/or expresse (actively) love. The 12 types were then regrouped into three pair types: matched, partial matched, and mismatched based on their passive or active expression of love languages.

Cook et al. (2013) did a construct validation on a measure based on the FLL theory. They used the FLL Scale to 185 participants to test the hypotheses that there were five major aspects of FLL. The results showed that there were five love languages, however, the components were different from the FLL theory proposed by Chapman. One of them was sacrificial love that includes sacrifice time, energy, and feelings to a spouse.

Because of contrasting and/or diverging results, this study aimed to test the construct validity of the FLL scale using factor analysis in Indonesia. We had also constructed the Indonesian version of the scale to add the contextual element on five love languages. Chapman (2010) states that love languages is a universal construct which can be found in various countries. Karandashev (2015) argues, however, that love is indeed a universal construct but manifests differently due to cultural impacts. For example, physical touch, such as hugs, can be an expression of love to one culture but it can be viewed as a sexual expression in a different culture.

Based on this notion, we aimed to validate love languages in Indonesia to test Chapman's proposal on the universality of love languages. The contextual element would be limited to language adjustment and item-writing formulation which will be discussed in the Method section. The results of this study were expected to be an empirical evidence supporting the multi-dimensional aspects of FLL.

This study would test various types of validities, such as content validity using professional judgments and construct validity using factor analysis. Steps in factor analysis started with a theoretical review of the measured concept. The next step was formulating the construct, identifying aspects and indicators, elaborating and writing the items. Construct formulation should be based on a synthesis of theories regarding theoretical concepts to be measured through a process of logical analysis and scrutiny.

\section{Method}

\section{Participants}

As the first study of FLL in Indonesia (claim made per July 2015), this study was conducted in Bali. Participants were adolescents aged at least 18 years old, singles and unmarried. In addition to their respective developmental stages, 18 years old are considered as an adult by law and regulations in Indonesia, therefore the participants were expected to have experiences in relationships. Relationship status/experiences was questioned in the personal information of the FLL scale. 
It should be noted that this study use an infinite population because the number of individuals in the group is not fixed and can change. Similar to many psychological studies that rely on university students as participants or sample (Hunsley \& Lee, 2014), this study also involved university students.

Participants were 400 undergraduate students of Universitas Dhyana Pura who were taken from the total population of 1,241 people using a proportionate random sampling method. The sample was consisted of 181 students of Management, 24 students of Psychology, 12 students of Pendidikan Anak Usia Dini (Early Childhood Education), nine students of Pendidikan Kesejahteraan Keluarga (Family Welfare), 17 students of English Literature, four students of Marketing, 50 students of Physiotherapy, 42 students of Medical Records, three students of Conservation Biology, 16 students of Nutritional Sciences, 21 students of Public Health Sciences, seven students of Information System, and 14 students of Informatics Engineering.

We divided 400 participants into several categories. Based on their gender, there were 148 males and 252 females. Based on their relationship status, 220 people were in a relationship, 164 were single, and 16 had never been dating before. The age of participants ranged from 18 to 27 years old $\left(M_{\text {age }}=19.85, S D_{\text {age }}\right.$ $=1.51)$. Predominantly, the ethnicity of participants was Balinese (289 students), whilst 31 students came from East Indonesia (Lombok, NTB, NTT, Ambon, Sulawesi, and Papua). Details of other ethnic groups can be seen in Figure 1.

The variable in this study was Five Love Languages proposed by Chapman (2010). Data of Five love languages were obtained from the scale of five love languages developed by the researchers based on Chapman's concept (2010), which measures the aspects of words of affirmation, quality time, receiving gifts, acts of service, and physical touch.

\section{Measures}

In the original version, Chapman introduced an ipsative scale for FLL. It has 40 paired items in which individuals were forced to choose one statement from each pair. However, an ipsative scale has disadvantages particularly when data are analysed with factor analysis. Englert (2010) stated that data obtained using an ipsative scale could not be analyzed thoroughly with factor analysis. An ipsative scale had also consistently showed a lower reliability compared to a normative scale.

Factor analysis is highly dependent on overall weight of each variable (Saville \& Willson, 1991). Therefore, data generated from a normative scale (such as a Likert scale) is expected to meet the characteristic of factor analysis as opposed to an ipsative scale. This shows why recent studies (Egbert \& Polk, 2006; Cook et al., 2013; and Polk \& Egbert, 2013) on love languages used Likert scale instead of Chapman's ipsative scale.

In this study, we constructed the Five Love Languages Scale. It consists of 34 statements using Likert scale with five alternative responses from 1 (strongly disagree) to 5 (strongly agree). Unlike Chapman's specific criterion scale (separate scales for husbands and wives), the Likert scale was constructed for both genders, singles, and/or married person. See Appendix A for further details of the 34-item scale.

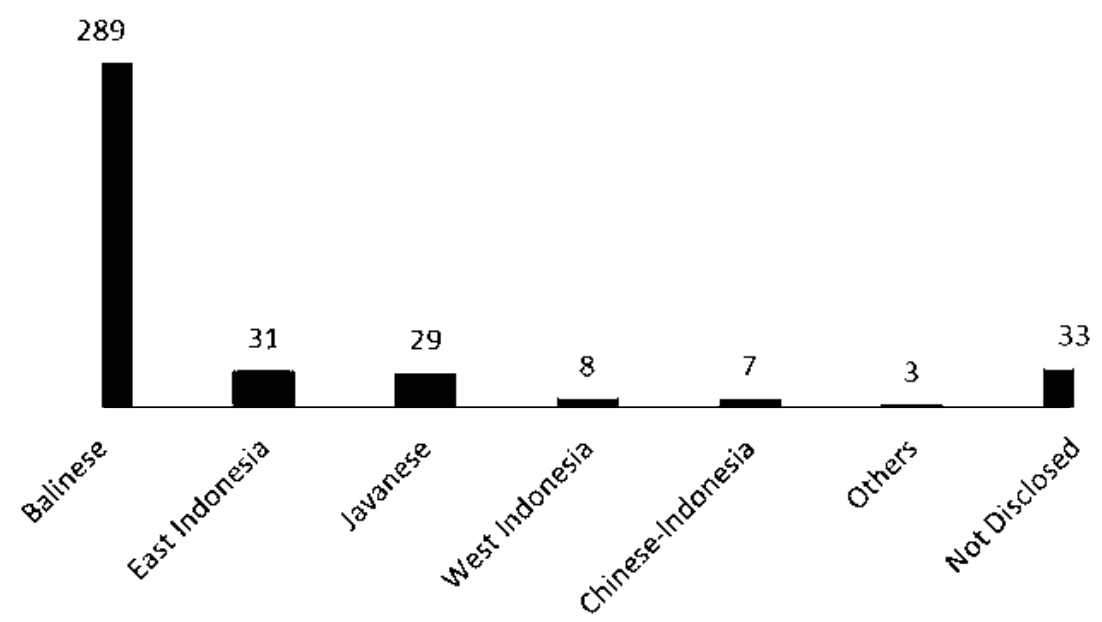

Figure 1. Ethnic groups of participants (Samples were mostly from Bali. Thirty three participants did not identify their ethnicity, whilst "Others" category were consisted of "Arabic" and "Portuguese" ethnic groups). 
As FLL is a new (and unproven) construct, it is important to create a large pool of items and define its components through factor analysis. A universal scale requires more items to be included in the analysis process. A universal scale would also allow a broader usage of the scale with different population. These benefits were clearly seen in a different construct, such as the big five personality model (Gosling, Rentfrow, \& Swann Jr., 2003).

\section{Data Analysis}

Data analysis used in this study was confirmatory factor analysis. Factor analysis is a statistical procedure for conducting construct validity. The analysis was performed using the SPSS version 16.0 for Windows.

\section{Validity and Reliability: 31 Items of the Five Love Languages Scale}

The first step conducted was testing the content validity of the scale. We were assisted by professional judges to evaluate if the items had covered the entire aspects of the theory being measured. Due to a lack of experts who are familiar with the Love Languages construct, we briefed a psychologist and psychology researcher on each components of FLL. They were then assigned to rate each item on its capability to represent the respective components of love languages.

We then tested the empirical validity of the scale by comparing the correlations between each item and the total items of the FLL scale. This resulted 31 items that had correlations ranged from .261 to .727 , which were more than or equal to .25 indicating that the scale had sufficient validity.

The results of the FLL's validity test were generally considered meeting the expectation. However, the number of items in the aspect of "acts of service" was still limited. If the coefficients of item-total correlations are calculated from a scale consisting of less-than-desirable number of items, it will increase the likelihood of the spurious overlap effect, that is, the possibility of obtaining correlation coefficients that are higher than actual values (overestimated values), because of the contribution of each item's scores to the scale scores (Azwar, 2013).

To minimize the occurrence of spurious overlap effects, we added three items to the aspect of "acts of service". The three items were selected based on a careful examination of the results of statistical analysis. We revised the items with a more specific behavior-based statement. For example, the initial item "I don't bother when my partner ignore my request for help" was changed into "feel loved ... when my parter accompany me to doctor." The three revised items were included in the Five Love Languages Scale (item number 2, 7, and 14). We then retested the items. All three items had item-total correlations of $.261, .405$ and .407 in the analysis.

It should be noted that the Five Love Languages scale measures composite attributes, the attributes were consisted of several aspects. Therefore, the reliability of the measure was calculated for each aspect, and the overall reliability was calculated using Moiser's formula to obtain a composite score (Azwar, 2013).The coefficient reliability obtained was a composite score of .884 . Thus, the instrument used in this study was reliable to measure the aspects of five love languages.

\section{Results}

\section{Item Selection}

The initial step to test construct validity was to define eigen-value of the five components. The subsequent step was to analyze the scale and its items based on the distribution patterns of the five loading factors in each component.

The items fell into the same component or factor were analyzed and grouped into one aspect of love languages. In contrast, items with loading factors below 0.20 were considered less suitable to be included in the scale. Those items were removed from the model.

This process extracted 17 valid items out of 34 items of the Five Love Languages Scale. Invalid items were reanalyzed using factor analysis to inspect mutual relationships between the aspects of the FLL. The step was taken to further confirm that all valid items supported the FLL construct. Table 1 shows the FLL components.

Table 1

Factors Considered as FLL Constituents

\begin{tabular}{cccr}
\hline Factor & Eigen Value & $\begin{array}{r}\text { Percent of } \\
\text { Variance }\end{array}$ & $\begin{array}{r}\text { Cumulative } \\
\text { Percent }\end{array}$ \\
\hline 1 & 5.108 & $30.046 \%$ & $30.046 \%$ \\
2 & 1.711 & $10.006 \%$ & $40.112 \%$ \\
3 & 1.281 & $7.533 \%$ & $47.645 \%$ \\
4 & 1.178 & $6.927 \%$ & $54.572 \%$ \\
5 & 1.003 & $5.9 \%$ & $60.472 \%$ \\
\hline
\end{tabular}


As shown in Table 1, the 17 items of FLL were analyzed using factor analysis to confirm the factors of FLL. The first step in determining the numbers of factors was to examine the eigen-values. The extraction method used in this study was Principal Component Analysis (PCA) and the rotation method used was Varimax. Appendix B provides more detailed results of the factor analysis.

We finally obtained five factors that were considered as the construct of five love languages. The five factors explained $60.47 \%$ of the variance of FLL (Table 1).

\section{Interpretation and Factor Labelling}

Interpretation and factor labelling were conducted by analyzing 17 valid items based on their distribution patterns. The 17 items were scattered, forming five factors with the total variance of $60.47 \%$. It was concluded that five love languages were influenced by the 17 items (Table 2).

Factor labelling or naming were based on the item distribution patterns. We carefully located items in each component according to the content and then decided the names of component based on the pattern formed.

For example, the first component consisted of items numbers 3,12,17, and 19. The items included statements such as "...diberi hadiah kejutan (given a surprise gift)...", "...pacar membelikan hadiah (my partner bought me a gift)...", "...mendapat hadiah kejutan (receiving a surprise gift)..." and "...diberi oleh-oleh (given a souvenir)...". Based on the content of items, component 1 was suitable to be titled "receiving gifts" because it was equivalent to an indicator of receiving gifts. The interpretation and names of the five components or factors can be seen in Table 2 .

Overall, the five factors constructing FLL was confirmed.They were words of affirmation, quality time, acts of service, receiving gifts, and physical touch. The components explained of $60.47 \%$ of the total variance of FLL. The five factors were represented by the 17 items in the FLL Scale.

\section{Score Categorization}

Using this valid scale, we develope a categorization of score to describe each aspect of FLL studied. The categorization was done using a formula based on standard deviation and theoretical mean (Azwar, 2013). We then used this to make a "genuine/pure category" and a cross tabulation in order to make the results more meaningful (see Table 3 ).
Table 2

Interpretation and Names of FLL Factors

\begin{tabular}{|c|c|c|c|c|c|}
\hline No. & Component & $\begin{array}{l}\text { Eigen } \\
\text { Value }\end{array}$ & Factor & $\begin{array}{l}\text { Item } \\
\text { No. }\end{array}$ & $\begin{array}{l}\text { Loading } \\
\text { Factor }\end{array}$ \\
\hline \multirow{4}{*}{1.} & \multirow{4}{*}{$\begin{array}{c}\text { Component } \\
1\end{array}$} & \multirow{4}{*}{1.178} & \multirow{4}{*}{$\begin{array}{l}\text { Receiving } \\
\text { Gifts }\end{array}$} & 3 & 0.767 \\
\hline & & & & 12 & 0.727 \\
\hline & & & & 17 & 0.492 \\
\hline & & & & 19 & 0.219 \\
\hline \multirow{4}{*}{2.} & \multirow{4}{*}{$\begin{array}{c}\text { Component } \\
2\end{array}$} & \multirow{4}{*}{5.108} & \multirow{4}{*}{$\begin{array}{l}\text { Words of } \\
\text { Affirmation }\end{array}$} & 1 & 0.454 \\
\hline & & & & 5 & 0.203 \\
\hline & & & & 9 & 0.326 \\
\hline & & & & 26 & 0.913 \\
\hline \multirow{3}{*}{3.} & \multirow{3}{*}{$\begin{array}{c}\text { Component } \\
3\end{array}$} & \multirow{3}{*}{1.711} & \multirow{3}{*}{$\begin{array}{l}\text { Quality } \\
\text { Time }\end{array}$} & 15 & 0.414 \\
\hline & & & & 21 & 0.727 \\
\hline & & & & 28 & 0.619 \\
\hline \multirow{3}{*}{4.} & \multirow{3}{*}{$\begin{array}{c}\text { Component } \\
4\end{array}$} & \multirow{3}{*}{1.281} & \multirow{3}{*}{$\begin{array}{l}\text { Acts of } \\
\text { Service }\end{array}$} & 2 & 0.497 \\
\hline & & & & 7 & 0.291 \\
\hline & & & & 14 & 0.740 \\
\hline \multirow{3}{*}{5.} & \multirow{3}{*}{$\begin{array}{c}\text { Component } \\
5\end{array}$} & \multirow{3}{*}{1.003} & \multirow{3}{*}{$\begin{array}{c}\text { Physical } \\
\text { Touch }\end{array}$} & 27 & 0.718 \\
\hline & & & & 30 & 0.33 \\
\hline & & & & 34 & 0.86 \\
\hline
\end{tabular}

Table 3

Range of Categorization

\begin{tabular}{lc}
\hline Range & Category \\
\hline$X \leq(\mu-1,5 \sigma)$ & Very low \\
$(\mu-1.5 \sigma)<X \leq(\mu-0.5 \sigma)$ & Low \\
$(\mu-0.5 \sigma)<X \leq(\mu+0.5 \sigma)$ & Average \\
$(\mu+0.5 \sigma)<X \leq(\mu+1.5 \sigma)$ & High \\
$(\mu+1.5 \sigma)<X$ & Very high \\
\hline
\end{tabular}

Table 4

Categorizing Participants

\begin{tabular}{cccr}
\hline No. & Aspects of FLL & Frequency & Percentage \\
\hline 1. & Words of Affirmation & 12 & $41.38 \%$ \\
2. & Quality Time & 3 & $10.34 \%$ \\
3. & Acts of Service & 6 & $20.7 \%$ \\
4. & Receiving Gifts & 5 & $17.24 \%$ \\
5. & Physical Touch & 3 & $10.34 \%$ \\
6. & Mixture & 371 & \\
& Total & 400 & $100 \%$ \\
\hline
\end{tabular}

Based on the score categorization in each aspect of FLL, we had the number of participants that had predominant scores in one aspect. In this case, the sample should be categorized as "high" or "very high" in one aspect and a category of "average" or "very low" in the other aspects. The participants fell into this category were called as participants in the "genuine/ pure category" or "exclusive category."

Of 400 participants, there were only 29 participants who fell into the "genuine category." The rest (371 participants) was categorized as "high" to "very high" 
on more than one aspect in the FLL scale. In other words, they had more than one primary love languages (Mixed Type; see Table 4).

In addition to categorizing participants into genuine or mixed category, we also analysed which love languages was more prevalent. Data were shown in Table 5 and Table 6.

Based on gender, the result show that most males and females fell into the "word of affirmation" type. This occurred both in the genuine category and whole sample.

\section{Discussion}

Few notable findings are discovered through factor analysis. We will start to discuss the "acts of service" component. Prior to factor analysis, three items were dropped and revised after inspecting their item-total correlations. The three items were rewritten due to weak item-total correlation scores. However, in the factor analysis, the three retained items were eliminated while the revised items convergently placed into one component: acts of service. All unfavorable items were also eliminated as the result of factor analysis.

We argue that this occurs because we have used a better approach and understanding with the concept while rewriting the items. The revised items were composed of effective sentences, positive (favorable) expressions, and used a specific "activity" related to feeling loved. An items such as "I didn't bother if my partner did not help me", was dropped in favor to an item such as "I feel loved when my partner took me to the doctor." Hence, an accurate item/content writing is essential to establish a valid scale.

Another finding which was expected was the elimination of item number 24: "I feel happy if my partner is present when I am sick." This item was initially located in the "receiving gifts" component (gift of self). Although it had initially passed the itemtotal correlation analysis, we considered it could be included in the "quality time" component. We had a difficulty in distinguishing gift of self and quality time as Chapman himself did not explain the differences between the two.

The results of factor analysis supported our prediction that the item number 24 did not specifically represent the concept of receiving gift in Five Love Languages. Thus, we suggest the necessity to understand and distinguish the concept of receiving gift (particularly the gift of self) and quality time. A further investigation must be held to gain a better under- standing of these components of Five Love Languages.

Compared to Egbert's and Polk's findings (2006), the five components of Chapman's love languages may have psychometric validity. Egbert and Polk indicates that five factor solution was far better than unidimensional, three, or four factor solution. Our study shows a promising result with five components of FLL. However, Egbert and Polk also correlated the FLL instrument with other established psychological instruments. This would be a further improvement for future studies to be considered; that is, to seek empirical findings by correlating the FLL instrument with other established scales.

Chapman (2010) has argued that each individual holds all five aspects of love languages. However, there is only one language which is more prevalent than others that makes people feel "most loved." This is called as "primary love language." The result of this study showed that most people had more than one primary love languages (371 participants or 92.75\%) which is similar to Chapman's statement.

The primary love language is formed throughout an individual's life span. As children develop their language by mimicking or learning from their parents or siblings, love languages is acquired in the same way. People can learn love languages from significant others in their family and each family member can have several different love languages. Thus, individuals might eventually develop more than one primary love languages (Chapman, 2010).

Chapman (2010) also proposes two conditions that could make people barely recognize their primary love language. The first condition occurs to individuals who feel loved intensively in various ways by their significant others. They then feel unsure about which love languages make them feel loved the most. The second condition occurs to individuals who never feel loved. The "vacancy" (or as Chapman said "empty love tanks") may make them uneasy and experiencing difficulties in determining what makes them feel loved the most. The difficulties lead them to have more than one primary love language.

As indicated in the result, most participants fell into the "words of affirmation" category. We explored this further by investigating participants' cultural backgrounds. Mesquita and Walker (2003) have explained that emotions in general have biological and sociocultural nature. It means emotions, such as feeling loved, may consist of autonomic response activity, cognitive appraisal, readiness, as well as cultural influences. Cultural domain of what is good could affect emotional practices within individuals. 
Table 5

Cross-Tabulation between FLL and Gender in Genuine Category

\begin{tabular}{lcccccc}
\hline & & \multicolumn{4}{c}{ Five Love Languages Aspect } \\
Sex & Male & Words of Affirmation & Quality Time & Acts of Service & Receiving Gifts & Physical Touch \\
\cline { 3 - 7 } & Female & 6 & 2 & 2 & 1 & 2 \\
Total & 6 & 1 & 4 & 4 & 1 \\
\hline
\end{tabular}

Table 6

Cross-Tabulation between FLL and Gender in Whole Sample

\begin{tabular}{lcccccc}
\hline & & \multicolumn{5}{c}{ Five Love Languages Aspect } \\
Sex & Male & Words of Affirmation & Quality Time & Acts of Service & Receiving Gifts & Physical Touch \\
\cline { 3 - 7 } & 103 & 44 & 49 & 46 & 39 \\
Total & 169 & 77 & 102 & 133 & 73 \\
\hline
\end{tabular}

Fernández, Carrera, Sánchez, Paez, and Candia (2000) wrote that Asians exert more cultural pressures in regulating and controlling affective expressions. They discovered that high power distance might influence others to repress their emotional expressions. It also affects them to have less verbal expressions on negative emotions. This study shows an interrelation of cultural influences and emotional experiences. This may be inferred from the expression of feeling loved.

Despite their diverse ethnicity, all of respondents were Indonesians. This is considered unique as Indonesians seldom give verbal praises or rewards (Kuntjara, 2003). Indonesians rarely deliver verbal compliments as this may lead to positive and negative outcomes. For example, parents never praise their child because they fear that their child will become arrogant or lazy.

Compared to praises, Indonesian people are more familiar with critics. The habit of criticizing other people usually occurs in family environment, academic setting, and even discussion forums (Pusparani, 2013). For example, in a class during students' presentation and "question and answer" sessions, the presenter usually receive criticism and involve in a debate instead of a scientific discussion. In newspapers, television, and other mass media, good news are seldom to be exposed as headlines in contrast to bad news.

Linking this to our research findings, the habit of providing less praises or verbal appreciation may influence participants to appreciate more to the verbal praises. Affirming words from their partner would be highly valued and make them feel loved. Further studies could explore this using a qualitative approach to investigate the reasons of a person developing the "words of affirmation" style.

Another aspect that can be improved is item elimination. Started with 34 items, we had to drop 17 items and retained the rest of 17 valid items. This might happen due to insensitivity in the process of writing items. Clark and Watson (1995) have emphasized that item writing should have a clear conceptualization of the targeted construct. As discussed above, this research brings a clearer understanding on each component of love languages, such as the necessity to differentiate Receiving Gift (gift of self) and Quality Time. The other examples, items number 22 and 33 of Words of Affirmation were eliminated as the result of factor analysis. We found that the two items were not clearly emphasized the feeling loved due to the use of a certain behavior but rather: "it is meaningful to hear support from my partner" and "I feel annoyed to receive 'Good Morning' text message from my partner everyday."

Brislin (1970) wrote the importance of gaining an equivalence between the source and target version (in this context, Indonesian version). This indicates that cultural influences may take part in item development and validity. For example, in the Physical Touch components, items which include physical contacts, such as hugging and embracing, were eliminated while items which contained touching hair or holding hands were kept in factor analysis. This is similar to our initial prediction when we constructed the Indonesian version of love languages. Although it is too early to conclude, but there might be a reservation toward hugging as opposed to merely holding hands or gentle stroke on the hair as the expressions of feeling loved.

\section{Limitations and Future Directions}

The FLL scale can be used by practitioners (such as psychologists and marriage counselors) as a helping tool as Chapman has originally intended with the scale. 
This Indonesian version of the scale can help therapists and couples to identify their love languages. A proper use of scale can help couples who have relationship issues to gain an insight or have a better understanding on their partners' needs. However, generalization of the results should be done carefully. The FLL scale was tested only in Bali for the time being. A further investigation is needed to develop the construct in a better way.

For future researchers, we recommend several future directions: Future researchers should replicate this study with a larger sample size and consider the representativeness of the sample based on the number of participants and diverse characteristics of the Indonesian population. Thus, it is expected that the results can be generalized to the entire Indonesian community. Further researchers are also expected to examine the relationships of FLL with other relevant variables, to investigate the implications of this theoretical concept in everyday life. An established measure, such as the big five personality test or other related measures (as demonstrated by Egbert \& Polk, 2006) may be used to to validate the FLL scale in addition to the use of factor analysis. Qualitative studies could also give an additional perspective on how FLL is shaped within individuals and the subjective meanings of each component of FLL.

\section{Conclusions}

This study aimed to validate Chapman's FLL construct in Indonesian version. Factor analysis indicated a promising result mirroring Chapman's initial construct and the results from previous studies (Egbert \& Polk, 2006). A five factor solution was the best fit for love languages as a construct as demonstrated by Cook et al. (2013). This extends empirical supports for Chapman's theory and opens the possibility to further validate the construct.

However, there were 17 out of 34 items eliminated in the process of validation. We hypothesized some possibilities to explain this. Furr (2011) suggested that modified scale should have different dimensionalities, reliability, and validity of the intended construct. Item writing process may impair the scale validity due to less specific and accurate sample of behavior in the respective components of love languages. Some items might be eliminated due to overlapping concepts between different components.

Winkler, Kanouse, \& Ware (1982) has indicated this issue in a scale development particularly when its structure is not well known. Participants tend to respond agreeably on item statement regardless of the content. This could increase inter-item correlations due to similar wordings eventhough the two components are not conceptually related. This overlapping might be problematic, such as in determining whether the "gift of self" should be categorised into Receiving Gift or Quality Time domain.

Notably, the result in this study indicated a pattern where most participants fell into the Words of Affirmation category (pure/mixed category). We have discussed the link between the cultural aspects regarding this finding and developed broader research questions on love languages. However, Furr (2011) emphasized that any psychological conclusion should consider psychometric properties and quality of current data. It indicates that the results of this study are bound to the time and context where the research were conducted. This opens to a further investigation among participants who are grouped into the Words of Affirmation category.

\section{References}

Al-Khalili, J., Perry, P., Baggini, J., Moyes, J., \& Wybourne, C. (2012). What is love? Five theories on the greatest emotion of all. Retrieved from http://www.theguardian.com/commentisfree/2012/d ec/13/what-is-love-five-theories

Azwar (2013). Penyusunan skala psikologi. Yogyakarta: Pustaka Pelajar.

Brislin, R. W. (1970). Back-translation for crosscultural research. Journal of Cross-Cultural Psychology, 1(3), 185-216.

Chapman, G. (2010). The 5 love languages: The secret to love that lasts. Chicago, IL: Northfield Pub.

Clark, L. A., \& Watson, D. (1995). Constructing validity: Basic issues in objective scale development. Psychological Assessment, 7(3), 309-319.

Cook, M., Pasley, J., Pellarin, E., Medow, K., Baltz, M., \& Buhmann-Wiggs, A. (2013). Construct validation of the five love languages. Journal of Psychological Inquiry, 18(2), 50-61.

Cookerly, J. R. (2010). The definition of love. Retrieved from http://whatislovedrcookerly.com/97/the-defi nition-of-love/

Egbert, N., \& Polk, D. (2006).Speaking the language of relational maintenance: A validity test of Chapman's (1992) five love languages. Communication Research Reports, 23(1), 19-26.

Englert. (2010). Ipsative tests: Psychometric properties. Retrieved from http://oprablog.wordpress.com/2010/ 
10/27/ipsative-tests

Fernández, I., Carrera, P., Sánchez, F., Paez, D., \& Candia, L. (2000). Differences between cultures in emotional verbal and non-verbal reactions. Psicothema, 12, 83-92.

Fraley, R. C., \& Shaver, P. R. (2000). Adult romantic attachment: Theoretical developments, emerging controversies, and unanswered questions. Review of General Psychology, 4, 132-154.

Furr, R. M. (2011). Scale construction and psychometrics for social and personality psychology. Singapore: SAGE Publications Asia-Pacific Pte Ltd.

Gonzaga, G., Keltner, D., Turner, R., Campos, B., \& Altemus, M. (2006). Romantic love and sexual desire in close relationships. Emotion, 6, 163-179.

Gosling, S. D., Rentfrow, P. J., \& Swann Jr., W. B. (2003). A very brief measure of the Big-Five personality domains. Journal of Research in Personality, 37, 504-528.

Hunsley, J., \& Lee, C. M. (2014). Introduction to clinical psychology: An evidence-based approach (3rd ed.). Toronto: John Wiley \& Sons.

Karandashev, V. (2015). A cultural perspective on romantic love. Online Readings in Psychology and Culture, 5(4). Retrieved from http://dx.doi.org/ 10.9707/2307-0919.1135

Kuntjara, E. (2003). Gender, bahasa dan kekuasaan.
Jakarta: Gunung Mulia.

Mesquita, B., \& Walker, R. (2003). Cultural differences in emotions: A context for interpreting emotional experiences. Behaviour Research and Therapy, 41, 777-793.

Polk, D. M., \& Egbert, N. (2013). Speaking the languages of love: On whether Chapman's (1992) claims stand up to empirical testing. The Open Communication Journal, 7, 1-11.

Pusparani, R. (2013). Analisis pengaruh budaya kerja eksplisit dan implicit terhadap perilaku kerja dan kinerja karyawan (Unpublished bachelor degree's thesis). Universitas Jember, Indonesia.

Saville, P., \& Wilson, E. (1991). The reliability and validity of normative and ipsative approaches in the measurement of personality. Journal of Occupational Psychology, 64, 219-238.

Suryabrata, S. (2000). Pengembangan alat ukur psikologis. Yogyakarta: Andi Offset.

Wilkins, R., \& Gareis, E. (2006). Emotion expression and the locution "I love you": A cross cultural study. International Journal of Intercultural Relations, 30, 51-75.

Winkler, J. D., Kanouse, D. E., \& Ware, J. E. (1982). Controlling for acquiescence response set in scale development. Journal of Applied Psychology, 67(5), 555-561. 


\section{Appendix A}

Items of FLL (34 items) in Bahasa Indonesia

\begin{tabular}{|c|c|c|}
\hline $\begin{array}{c}\text { No. } \\
\text { Butir/Items }\end{array}$ & Pernyataan/Statements & $\begin{array}{r}\text { Komponen/ } \\
\text { Components }\end{array}$ \\
\hline 1 & $\begin{array}{l}\text { Saya merasa sangat bahagia ketika pacar mengatakan bahwa ia bangga terhadap } \\
\text { saya/I feel overjoyed when my partner says he/she is proud of me }\end{array}$ & $\begin{array}{r}\text { Words of } \\
\text { Affirmation }\end{array}$ \\
\hline 9 & $\begin{array}{l}\text { Sangat berarti bagi saya ketika pacar bersedia memaafkan kesalahan saya/It is most } \\
\text { important for me when my partner is willing to pardon my mistakes }\end{array}$ & \\
\hline 22 & $\begin{array}{l}\text { Sangat berarti bagi saya ketika mendengar kata-kata dukungan/motivasi dari pacar/ } \\
\text { It is most meaningful for me to hear supportive/motivational words from my partner }\end{array}$ & \\
\hline 26 & $\begin{array}{l}\text { Saya merasa sangat bahagia ketika mendengar pacar mengatakan bahwa ia } \\
\text { mengagumi saya/I feel elated when I hear my partner says that he/she admires me }\end{array}$ & \\
\hline 31 & $\begin{array}{l}\text { Saya merasa paling dicintai ketika mendengar pacar memuji saya atas pekerjaan } \\
\text { saya/I feel most loved when I hear my partner praises me of what I do }\end{array}$ & \\
\hline $5^{*}$ & $\begin{array}{l}\text { Saya tidak nyaman ketika pacar memuji saya di depan orang lain/I feel } \\
\text { uncomfortable when my partner praises me in front of other people }\end{array}$ & \\
\hline $16^{*}$ & $\begin{array}{l}\text { Saya merasa risih ketika pacar mengucapkan kata-kata romantis/I feel annoyed } \\
\text { when my partner says romantic words }\end{array}$ & \\
\hline $33^{*}$ & $\begin{array}{l}\text { Saya terganggu menerima pesan (SMS/note/email) "selamat pagi" dari pacar setiap } \\
\text { hari/ I am bothered to receive text message/E-mail such "good morning" from my } \\
\text { partner everyday }\end{array}$ & \\
\hline 10 & $\begin{array}{l}\text { Saya sangat senang jika dapat jalan-jalan dengan pacar/I feel excited if I could go } \\
\text { out with my partner }\end{array}$ & Quality Time \\
\hline 21 & $\begin{array}{l}\text { Saya merasa paling bahagia ketika pacar bersedia mendengarkan cerita saya } \\
\text { dengan penuh simpati/I feel happiest when my partner is willing to listen to my } \\
\text { stories symphatetically }\end{array}$ & \\
\hline 28 & $\begin{array}{l}\text { Sangat berarti bagi saya ketika pacar mau berbagi pengalaman masa lalu dan } \\
\text { pemikirannya tentang masa depan/It is most meaningful for me when my partner is } \\
\text { willing to share his/her past and thoughts about future }\end{array}$ & \\
\hline $6^{*}$ & $\begin{array}{l}\text { Saya merasa resah jam belajar saya terganggu, ketika pacar berkunjung ke rumah/I feel } \\
\text { anxious my studying schedule is interrupted when my partner visits me at home }\end{array}$ & \\
\hline $15^{*}$ & $\begin{array}{l}\text { Menghabiskan waktu seharian bersama pacar, menurut saya berlebihan/To spend } \\
\text { the whole day with partner is over the top }\end{array}$ & \\
\hline $23 *$ & $\begin{array}{l}\text { Saya merasa tertekan ketika harus meluangkan waktu berdua dengan pacar/I feel } \\
\text { burdened to spend time together with my partner }\end{array}$ & \\
\hline $32 *$ & $\begin{array}{l}\text { Saya merasa terganggu ketika pacar menemani saya ke mana-mana/I feel disturbed } \\
\text { when my partner accompany me all the time }\end{array}$ & \\
\hline 2 & $\begin{array}{l}\text { Saya merasa dicintai ketika pacar mengantar saya berobat ke dokter/ I feel most } \\
\text { loved when my partner takes me to visit a doctor }\end{array}$ & Acts of Service \\
\hline 14 & $\begin{array}{l}\text { Saya merasa dicintai ketika pacar membantu saya saat dibutuhkan/I feel most loved } \\
\text { when my partner helps me when needed }\end{array}$ & \\
\hline 20 & $\begin{array}{l}\text { Saya merasa dicintai ketika pacar menolong mengerjakan tugas rumah dengan } \\
\text { inisiatif sendiri/I feel most loved when my partner helps me with chores on his/her } \\
\text { own initiative }\end{array}$ & \\
\hline $7^{\wedge}$ & $\begin{array}{l}\text { Saya merasa dibantu oleh pacar mengerjakan tugas adalah hal yang romantis/I feel } \\
\text { that it is something romantic to be helped by partner to do some tasks }\end{array}$ & \\
\hline $11^{*}$ & $\begin{array}{l}\text { Saya tidak ambil pusing ketika pacar mengabaikan permintaan tolong saya/I don't } \\
\text { bother if my partner neglects my request for help }\end{array}$ & \\
\hline $29 *$ & $\begin{array}{l}\text { Saya merasa tidak nyaman ketika pacar membantu bersih-bersih di rumah/I feel } \\
\text { uncomfortable if my partner helps me to clean up the house }\end{array}$ & \\
\hline 8 & $\begin{array}{l}\text { Saya merasa paling dicintai ketika diberi hadiah oleh pacar/I feel most loved when I } \\
\text { receive a gift from my partner }\end{array}$ & $\operatorname{Rec}$ \\
\hline
\end{tabular}




\begin{tabular}{|c|c|c|}
\hline $\begin{array}{l}\text { No. } \\
\text { Butir/Items }\end{array}$ & Pernyataan/Statements & $\begin{array}{l}\text { Komponen/ } \\
\text { Components }\end{array}$ \\
\hline 12 & $\begin{array}{l}\text { Saya merasa paling dicintai ketika pacar membelikan hadiah berupa barang yang } \\
\text { saya inginkan/I feel most loved when my partner bought me stuffs that I need as a gift }\end{array}$ & \\
\hline 17 & $\begin{array}{l}\text { Sangat berarti bagi saya ketika mendapat hadiah kejutan dari pacar/It is most } \\
\text { meaningful when I got a surprise gift from my partner }\end{array}$ & \\
\hline 24 & $\begin{array}{l}\text { Saya sangat bahagia ketika pacar hadir di saat saya sedang merasa sedih/I feel } \\
\text { happy when my partner is present when I am down-hearted }\end{array}$ & \\
\hline $3 *$ & $\begin{array}{l}\text { Saya tidak senang diberi hadiah kejutan oleh pacar, apalagi tidak sedang berulang- } \\
\text { tahun/I am unhappy to be given a surprise gift by my partner, especially when it's } \\
\text { not my birthday }\end{array}$ & \\
\hline $19 *$ & $\begin{array}{l}\text { Menurut saya berlebihan jika pacar memberi oleh-oleh setiap kali ia pulang dari } \\
\text { berpergian/I think it's over the top if my partner brings souvenirs everytime he/she } \\
\text { goes home after travelling }\end{array}$ & \\
\hline 4 & $\begin{array}{l}\text { Saya sangat senang ketika dipeluk pacar/I feel extremely happy being hugged by } \\
\text { my partner }\end{array}$ & Physical Touch \\
\hline 13 & $\begin{array}{l}\text { Sangat berarti bagi saya ketika pacar menenangkan saya dengan mengusap punggung } \\
\text { saya/It is most essential for me when my partner soothe me by rubbing my back }\end{array}$ & \\
\hline 25 & $\begin{array}{l}\text { Saya merasa paling dicintai ketika pacar mencium kening saya/I feel most loved } \\
\text { when my partner kisses my forehead }\end{array}$ & \\
\hline 30 & $\begin{array}{l}\text { Saya sangat senang ketika pacar menggenggam tangan saya ketika sedang duduk } \\
\text { berdampingan/I feel elated when my partner holds my hand while we sit next to each other }\end{array}$ & \\
\hline $18 *$ & $\begin{array}{l}\text { Saya merasa tidak nyaman ketika bergandengan tangan dengan pacar saat jalan- } \\
\text { jalan/I feel uncomfortable to hold hands with my partner while we walk together }\end{array}$ & \\
\hline $27 *$ & $\begin{array}{l}\text { Saya merasa terganggu ketika pacar membelai rambut saya/I feel agitated when my } \\
\text { partner caresses my hair }\end{array}$ & \\
\hline $34 *$ & $\begin{array}{l}\text { Saya tidak suka cara bercanda pacar dengan menggelitik/mencubit/mendorong / I } \\
\text { don't like the way my partner cracks a joke by tickling/pinching/pushing }\end{array}$ & \\
\hline
\end{tabular}




\section{Appendix B}

Principal Component Analysis Result

\begin{tabular}{lccccc}
\hline & & \multicolumn{3}{c}{ Component } & \\
& 1 & 2 & 3 & 4 & \\
\hline Word1 & .338 & .454 & .349 & .660 \\
Word2 & & .203 & .721 & \\
Word3 & .326 & & .297 \\
Word6 & .217 & .913 & .414 & .497 \\
Time1 & .312 & .212 & .727 & .291 \\
Time4 & & & .619 & .740 \\
Time6 & .343 & & .477 & \\
Act1 & .279 & & & .253 \\
Act2 & .326 & .208 & .247 & .374 \\
Act4 & .767 & .200 & & .417 \\
Gift1 & .727 & .913 & & \\
Gift3 & .492 & & & .318 \\
Gift4 & .219 & & & \\
Gift5 & .571 & & & \\
Touch5 & & & & \\
Touch6 & & & & \\
Touch7 & & & & \\
\hline
\end{tabular}

